\title{
PENGARUH ORIENTASI PASAR, INOVASI PRODUK, DAN KEMAMPUAN \\ PEMASARAN TERHADAP KINERJA BISNIS
}

Angelita Nauli Panggabean - 2301950881 - LB21

E-Business Strategy and Implementation

\begin{abstract}
Abstrak
Tujuan dari tinjauan pustaka ini adalah untuk mengeksplorasi perilaku yang dilakukan perusahaan dengan mengindentifikasi pengaruh ketiga faktor, antara lain orientasi pasar, inovasi produk, dan kemampuan pemasaran terhadap kinerja bisnis. Metode yang digunakan adalah dengan mengumpulkan serta mempelajari jurnal-jurnal. Jurnal tersebut didapatkan dari berbagai sumber melalui internet. Dari jurnal-jurnal tersebut, dapat disimpulkan bahwa orientasi pasar, inovasi produk, dan kemampuan pemasaran memiliki pengaruh yang signifikan terhadap kinerja bisnis.
\end{abstract}

Kata Kunci: Orientasi Pasar, Inovasi Produk, Kemampuan Pemasaran

\section{Pendahuluan}

Di tengah persaingan saat ini, perusahaan dituntut untuk memiliki strategi yang tepat demi mewujudkan pertumbuhan dan keberlangsungan usaha jangka panjang. Persaingan saat ini sangat kompleks dan pesat, dimana banyaknya produk baru, teknologi baru, serta pesaing baru yang muncul. Dalam situasi mengacam ini pun, pelanggan memiliki banyak permintaan dan tuntutan untuk mendapatkan kualitas barang atau jasa yang baik dengan harga murah. Dengan demikian, penting bagi perusahaan untuk memperhatikan dan mengembangkan orientasi pasar demi menarik dan mempertahankan pelanggan. Perusahaan yang berorientasi pada pasar merupakan perusahaan yang berfokus pada memenuhi kebutuhan dan keinginan pelanggan, atau menjadikan kesuksesan perusahaan tersebut bergantung pada kepuasan pelanggan.

Konsumen yang semakin kritis dalam memilih produk serta persaingan yang pesat pun telah menuntut perusahaan untuk melakukan inovasi. Inovasi merupakan salah satu faktor yang menjadi kunci keberhasilan sebuah perusahaan. Inovasi memiliki arti sebagai gagasan baru yang diterapkan untuk menciptakan atau memperbaharui suatu produk yang berbeda dan jauh lebih baik dari pada produk pesaing. Perusahaan dituntut untuk mampu menciptakan dan mengembangkan ide-ide baru, menawarkan produk-produk yang inovatif, serta mengimplementasikan ide kinerja layanan baru yang memuaskan pelanggan. Dalam bisnis, inovasi produk akan memberikan peluang yang besar bagi perusahaan untuk menarik lebih banyak konsumen. Faktor lainnya yang dapat mempengaruhi performa bisnis adalah kemampuan pemasaran. Faktanya, masih banyak perusahaan yang kurang memiliki keterampilan dan pengetahuan tentang pemasaran dasar. Dengan begitu, perusahaan perlu memiliki kreativitas dalam menyusun strategi pemasaran demi mempertahankan kinerja bisnis. Dengan kata lain, orientasi pasar, inovasi produk, dan kemampuan 
pemasaran merupakan faktor yang dapat mempengaruhi performa bisnis. Oleh karena itu, telah membuat penulis tertarik untuk mengeksplorasi perilaku yang dilakukan perusahaan dengan mengindentifikasi pengaruh ketiga faktor tersebut.

\section{Literature Review}

\section{Orientasi Pasar}

Orientasi pasar merupakan keadaan dimana perusahaan menjadikan pelanggan sebagai kiblat untuk menjalankan bisnisnya (Utaminingsih et al., 2016). Perusahaan yang berorientasi pasar merupakan perusahaan yang mampu memahami mengenai apa yang dibutuhkan dan diinginkan pelanggannya. Menurut Narver dan Slater, orientasi pasar terdiri dari tiga komponen perilaku, yakni orientasi pelanggan, orientasi pesaing, dan koordinasi antar fungsional. Orientasi pelanggan disini merupakan pemahaman perusahaan terhadap pembeli sasaran sehingga dapat menciptakan nilai-nilai kepuasan pelanggan; orientasi pesaing, yaitu merupakan pemahaman suatu perusahaan akan kekuatan dan kelemahan jangka pendek serta strategi jangka panjang dari para pesaing, baik yang sudah ada maupun yang akan muncul; dan koordinasi antar fungsi, yaitu merupakan koordinasi pemanfaatan sumber daya dalam perusahaan antar berbagai departemen demi memberikan respon yang tepat kepada pelanggan. Manfaat yang didapatkan bagi perusahaan yang berorientasi pasar, antara lain dapat membantu perusahaan dalam memproduksi barang atau jasa secara lebih efisien dibandingkan dengan pesaing; membantu memproduksi barang atau jasa yang sesuai dengan kebutuhan dan keinginan pasar; serta menjelaskan perusahaan tentang perbedaan-perbedaan kinerja yang telah dicapai.

\section{Inovasi Produk}

Inovasi produk menurut Myres dan Marquis dalam Kotler adalah gabungan dari berbagai macam proses yang saling mempengaruhi antara satu dengan yang lain. Inovasi produk terdiri dari berbagai kegiatan mulai dari pengembangan produk baru, perbaikan produk, hingga perluasan jumlah lini produk yang ditawarkan perusahaan. Inovasi produk didefinisikan sebagai sebuah mekanisme perusahaan untuk dapat beradaptasi di tengah persaingan dengan menciptakan nilai dan ide baru, menawarkan produk yang inovatif, serta meningkatkan kinerja layanan yang baik. Atribut inovasi produk menurut Kotler \& Amstrong (2004) mencakup kualitas produk, fitur produk, serta gaya dan design produk. Inovasi produk ini pun dapat dicapai melalui pengenalan akan teknologi baru dalam produk-produk yang ditawarkan perusahaan. Dalam perusahaan, inovasi produk merupakan salah satu faktor yang berperan penting dalam membangun dan mengembangkan serta meningkatkan profitabilitas perusahaan. Dengan kata lain, inovasi dapat menjadi sebuah fungsi penting dari perusahaan untuk menentukan suatu kinerja bisnis. Inovasi menjadi penting tidak hanya sebagai pertumbuhan perusahaan, tetapi juga dalam persaingan di pasar. Berdasarkan penelitian oleh (Hida Syahchari et al., 2019), menemukan bahwa inovasi produk memiliki pengaruh yang signifikan terhadap performa bisnis. 


\section{Kemampuan Pemasaran}

Kemampuan pemasaran didefinisikan sebagai kemampuan perusahaan dalam memahami dan memenuhi kebutuhan pelanggan pada waktu yang tepat, tempat yang tepat, dan juga biaya yang tepat. Kemampuan marketing juga dapat digambarkan sebagai kemampuan atau kinerja perusahaan dalam menjalankan aktivitas pemasaran mulai dari memperkenalkan produk dan bisnis, membangun posisi dalam pasar, mengenali target pasar, mendistribusikan barang yang dapat memuaskan pelangga, hingga mengatur dan mencapai target penjualan dan keuntungan perusahaan. Tujuan kemampuan pemasaran dalam sebuah perusahaan, antara lain memaksimalkan keuntungan, memaksimalkan penjualan, memaksimalkan pangsa pasar, meningkatkan kepuasan pelanggan, meningkatkan citra merek, serta menjaga stabilitas orientasi pasar (Hida Syahchari et al., 2019). Dengan demikian, kemampuan pemasaran juga menjadi salah satu faktor sangat penting untuk kinerja bisnis yang berkelanjutan.

\section{Kinerja Bisnis}

Kinerja bisnis merupakan hasil-hasil evaluasi kegiatan dalam suatu perusahaan yang dipengaruhi oleh faktor internal dan eksternal dalam mencapai tujuan perusahaan. Kinerja bisnis tidak hanya dilihat dan diukur secara objektif atau finansial, tetapi juga harus diukur dengan pengukuran subjektif atau non-finansial. Kinerja bisnis yang dapat dilihat dengan pendekatan objektif adalah melalui kinerja keuangan yang diukur melalui tingkat solvabilitas, likuiditas, dan profitabilitas perusahaan. Sedangkan, kinerja bisnis yang diukur dengan pendekatan subjektif adalah melalui kinerja non-ekonomi atau kinerja non-keuangan, dimana terdiri dari dominasi dalam pasar, kinerja pasar, kualitas layanan yang diberikan, valuasi pasar, produktivitas, kekuatan pemasok, konsetrasi penjualan, reputasi perusahaan, kesetiaan pelanggan, dan komitment perusahaan (Hida Syahchari et al., 2019). Kinerja merupakan hal penting yang harus dicapai oleh setiap perusahaan. Hal ini karena, kinerja merupakan cerminan dari kemampuan perusahaan dalam melakukan aktivitas bisnisnya, seperti mengelola dan mengalokasikan sumber dayanya.

\section{Metode}

Karya tulis ini dibuat dengan metode literature review atau tinjauan pustaka, dimana penulis mengumpulkan dan mempelajari jurnal-jurnal. Jurnal tersebut didapatkan dari berbagai sumber melalui internet.

\section{Kesimpulan}

Tujuan dari tinjauan pustaka ini adalah untuk mengeksplorasi perilaku yang dilakukan perusahaan dengan mengindentifikasi pengaruh ketiga faktor, antara lain orientasi pasar, inovasi produk, dan kemampuan pemasaran terhadap kinerja bisnis. Berdasarkan penelitian (Utaminingsih et al., 2016), bahwa orientasi pasar memiliki pengaruh positif dan signifikan terhadap kinerja perusahaan. Selain itu, berdasarkan penelitian yang dilakukan oleh (Hida Syahchari et al., 2019), 
bahwa diperoleh data dari hasil analisis yang menunjukkan bahwa orientasi pasar, inovasi produk, dan kemampuan pemasaran memiliki pengaruh yang signifikan terhadap kinerja bisnis. Variabel yang paling memiliki pengaruh yang signifikan adalah variable inovasi produk diikuti oleh variabel kemampuan pemasaran dan terakhir variabel orientasi pasar. Dengan demikian, perusahaan penting untuk melakukan inovasi produk di tengah persaingan bebas seperti saat ini, seperti menciptakan ide-ide dan nilai-nilai baru, menciptakan produk yang inovatif, serta meningkatkan kinerja pelayanan yang memuaskan pelanggan.

\section{Reference:}

Hida Syahchari, D., Saroso, H., \& Hartono, H. (2019). Effect of Market Orientation, Marketing Capability, Product Innovation on Performance. In International Journal of Innovation, Creativity and Change. www.ijicc.net (Vol. 10, Issue 8). www.ijicc.net

Nuvriasari, A., Mercu, U., \& Yogyakarta, B. (n.d.). Ekuitas: Jurnal Ekonomi dan Keuangan Gumirlang Wicaksono Sumiyarsih.

Utaminingsih, Adijati. (2016). Pengaruh Orientasi Pasar, Inovasi, dan Kreativitas Strategi Pemasaran Terhadap Kinerja Pemasaran Pada UKM Kerajinan Rotan Di Desa Teluk Wetan, Welahan, Jepara. In Media Ekonomi Dan Manajemen, 10(2)

Elwisam, Lestari, R. (2019). Penerapan Strategi Pemasaran, Inovasi Produk Kreatif dan Orientasi Pasar Untuk Meningkatkan Kinerja Pemasaran UMKM. In Jurnal Riset Manajemen dan Bisnis (JRMB) Fakultas Ekonomi UNIAT, 4(2) 